through the National Endowment for the Humanities. The Department is training professional translators in the humanities and the sciences and developing new learning methods in the field of intercultural communications. Activities have also been expanded in the field of literary translation and a translation workshop has been operating annually since spring $197 \mathrm{I}$ in French, German, Spanish, and Latin. With the creation of the centre the curriculum has been widened to include classical and modern Chinese, Russian, Polish, and Yiddish; staff have also been engaged for Biblical and modern Hebrew.

The centre intends to hold a regular series of forums on subjects related to translation and to act as a clearing-house for translations in progress, translations under contract, and works needing translation. The Director of the Centre is Mr. Gerald Gillespie, Professor of German and Comparative Literature. Communications should be addressed to Ms. Marilyn Gaddis Rose, Chairman of the Department of Comparative Literature and Acting Director of the Centre, or to Mr. Ramon Layera, Ibero-American Consultant and Administrative Assistant, at SUNY Binghamton, New York r 390 r.

\title{
International African Bibliography
}

THE bibliographical card-index service offered until 1972 by the International African Institute is now available in the Library of the School of Oriental and African Studies.

Cards giving details of monographs, pamphlets, articles, conference papers, and items within collected works are arranged by geographical region/country, thence the subject. The subject approach is a feature not included in the quarterly International African Bibliography. The majority of entries at present refer to works published in 1972 and 1973 . The card-index will, of course, grow as fresh cards are added annually. An author card-index is also available.

Staff and students of the School may consult the card-index in Room F2 of the Library.

\section{OXFAM: New Voluntary Overseas Group}

Proples from the developing countries of Africa, Asia, and Latin America are being sought by Oxfam's branch in Central London for a new voluntary group designed to back up the agency's world-wide development programme. The group will have two principal functions: to advise on policies that would encourage a more positive attitude towards world development, and to help generate new support for Oxfam's work. It will be one of several special groups recently set up by Oxfam in London. This first Overseas Group will be limited to people living in and around London. Anyone interested in further information should contact Miss Jeannie Murray, Oxfam Regional Office, I 2 Crane Court, Fleet Street, London EC4 (Telephone: o1-353-5701).

\section{'Cultures et développement' (Université Catholique de Lowvain) vol. v, no. 4.} Articles

Richard D. Ralston. Political Change in Colonial African Leadership (ca. 1914-ca. 1945): American and Afro-American Influences.

Béatrice de Sinçay. Christianisme et développement au Rwanda Central.

Samuel Decalo. The Colonel in Command Car. Towards a Re-examination of Motives for Military Intervention in Africa.

Marc A. Tessler. Le concept de modernité au miroir des sciences sociales.

Aryé Globerson. Participation et développement. 


\section{Comptes Rendus}

Ouvrages envoyés à la rédaction.

Bibliographie des Sciences du Développement.

\section{Tarifs d'Abonnement}

4 numéros par volume, I volume par an. Belgique : F.B. 60o. Étranger F.B. 690 ou l'équivalent en monnaie du pays. A payer par virement ou chèque bancaire à la Société Générale de Banque à Leuven (C.C.P. 9.82), pour le compte n' $230-0048 . \times 19-27$ de 'Cultures et développement'. Adresse: 62, Tervuurse Vest, 3000 Leuven (Belgique). Tél. (016) 333.32.

\section{LETTERS TO $A F R I C A$}

Letters to the Editor should refer to matters raised in the journal and should not exceed 450 words in length. They should be signed and give full address and position of the writer. The Editor reserves the right to shorten letters or to decline them.

From Dr. Charles D. Laughlin, Visiting Fellow, University of Pennsylvania

$\mathrm{Sir}$, I regret that Mr. Weatherby found our article on the ghost cult in So (January 1972) to be so sadly misleading and replete with faulty information. Let me address myself briefly to the concerns expressed in his letter in the January issue of this journal:

First, I cannot but agree with Weatherby's observation (identical to our own on p. 12 of the article) that the kenisan on all three mountains must agree on the holding of an initiation ceremony. I must also agree that a few kenisanat will state that the initiation ceremony should occur either on Kadam or Moroto (preferably the former). But as an anthropologist I am perhaps oversensitive to the distinction between statement de jure and models of actual social process. I cannot ignore the fact that the last ceremony which occurred in 1953 was held in all three sections.

Mr. Weatherby is also correct when he says that cases of theft are not 'brought before the kenisan'. As we mention in the article (p. I2) such matters are brought before the council of elders, some of whom are members of kenisan. Under normal circumstances, thefts are cleared in council. However, if the perpetrator is not discovered, then, and only then, will the matter become of concern to the kenisan.

It is indeed not correct to say that women were the first kenisan, and had we said that we would be seriously in error. We said that the So believe women to have been, for a brief time, the first kenisanthereby manifesting a distinction between mythic representation and reality. I regret that this distinction has confused Mr. Weatherby.
The historical and functional relationships between the age generation system and kenisan will be explored in detail in a forthcoming article in the July 1974 issue of this journal. Mr. Weatherby is quite right to emphasize that, generally speaking, the status of a man in So society will accrue to his son when that status is the result of wealth and/or standing in kenisan. However, according to our kenisan informants there never has been a time when junior males, of whatever status, participated in council. I find it remarkable that Mr. Weatherby is able to make statements of such certainty about the political process in So before the advent of the formal age generation system-a happening he claims to have occurred prior to the early nineteenth century. In fact, the present age generation system in So was borrowed by them from the Karamojong sometime after I9oo.

God, or belgen, is said to dwell in the sky, on the mountain tops, and in the mountain streams, depending upon the circumstances under which he is mentioned. The water sprite, tegnee, is said to dwell in still pools of water where people bathe.

I find myself puzzled by statements in the last paragraph of Mr. Weatherby's letter which seem to hint at, but never specify, some dark doings or methodological inadequacies on our part. I do hope that in the future, at least, a simple sense of fairness to those about whom he writes in public print will restrain him from innuendo.

Yours faithfully

Charles D. Laughlin

Philadelphia 